\title{
Persepsi Masyarakat Kota Terhadap Otonomi Daerah
}

\author{
Irtanto
}

The result of research indicates that people tend to be a-priory to autonomous region because they have gotten information of decentralization from perception of media editorial and interpersonal. So, the government and social institutions should take the role of socialization beside the media itself.

\section{Pendahuluan}

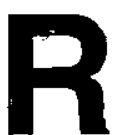

eformasi, merupakan jargon yang sangat terkenal di bumi Indonesia saat ini. Reformasi ingin membalik sesuatu yang sentralisme menjadi desentralisasi, otoriterisme dibalik menjadi demokratis. Wujud tuntutan reformasi yang membalik sistem sentralistik menjadi desentralisasi dan otoriterisme menjadi demokratis, secara radikal telah melahirkan Undang-Undang No. 22 tahun 1999 tentang pemerintahan daerah yang lebih dikenal dengan undang-undang otonomi daerah, dan Undang-Undang No. 25 tahun 1999 tentang perimbangan keuangan antara pusat dan daerah.

Kedua undang-undang yang dilahirkan di masa reformasi tersebut pada dasarnya mengatur pelaksanaan otonomi daerah yang dititik beratkan pada kabupaten/kota. Selain itu, telah merubah pola pendekatan dari "atas ke bawah" menjadi "bawah ke atas". Substansi UU No. 22 tahun 1999 dan 25 tahun 1999 adalah memberi wewenang penuh kepada daerah untuk mengelola semua urusan rumah tangganya sendin, kecuali 5 (lima) hal yang menyangkut pertahanan-keamanan, politik luar negeri, agama, kehakiman, moneter dan fiskal.

Desentralisasi sangat memberi arti yang signifikan bagi pertumbuhan demokrasi, ekonomi, maupun lainnya yang ada $\cdot d i$ daerah. Undang-undang tersebut menempatkan pemerintah daerah menjadi sangat penting peranaannya dalam mengelola kepentingan rakyat. Pemerintah daerah harus lebih responsif, aspiratif terhadap berbagai kebutuhan masyarakat. Undang-undang itu, selain memberi berbagai keuntungan kepada daerah juga tidak jarang pula menimbulkan berbagai persoalan baru sebagai akibat kurangnya pemahaman. Implikasi negatif yang ditimbulkan akibat salah pemahaman terhadap otonomi daerah, seperti munculnya sikap euforia daerah dan sikap arogansi di berbagai kalangan.

Untuk mengeliminasi berbagai persoalan yang dapat berimplikasi negatif pada desintegrasi daerah yang lebih parah, maka otonomi daerah terlebih dahulu harus dipahami, dimengerti oleh berbagai kalangan yang hidup di masyarakat, sehingga terbentuklah pemahaman yang relatif sama. 
Bila ada pemahaman (persepsi) yang relatif sama diharapkan dalam pelaksanaannya dapat berjalan lancar, tanpa menimbulkan berbagai distorsi yang dapat menghambat pembangunan lokal maupun nasional.

Sebagai akibat pemahaman yang keliru terhadap otonomi daerah tidak jarang pula menimbulkan berbagai persoalan. Pemahaman yang keliru tersebut sebagai salah satu akibat kurang maksimalnya informasi yang mereka terima, ataupun mereka menerima informasi namun mengalami berbagai distorsi. Ekses negatif otonomi daerah memunculkan sikap arogansi di sejumlah daerah yang tidak mau lagi berkoordinasi dengan pemerintah propinsi Tidak jarang pula menimbulkan berbagai konflik kepentingan baik secara horizontal maupun vertikal yang berakibat hubungan kelembagaan semakin tidak harmonis, dan hubungan sinergis terabaikan.

Mengingat UU No. 22 tahun 1999 dan UU No.25 tahun 1999 mempunyai peranan yang cukup mendasar bagi pembangunan daerah kabupaten/kota. Difusi informasi tentang desentralisasi menjadi sangat penting untuk dipahami, dimengerti, karena sering mengundang banyak arti dan makna sehingga keakuratan sumber informasi akan turut pula mewamai tingkat pemahaman (persepsi) berbagai pihak. Oleh karena itu sebelum undang-undang otonomi daerah dilaksanakan lebih jauh, maka menjadi menarik untuk kita kaji lebih mendalam tentang persepsi dan peranan komunikasi yang menyangkut tentang otonomi daerah.

Permasalahan yang menjadi kajian dalam penelitian ini adalah bagaimana persepsi masyarakat terhadap otonomi daerah? Dan faktor apa yang mempenganuhi persepsi masyarakat terhadap otonomi daerah? Dari media apa masyarakat mendapatkan informasi mengenai otonomi daerah? Seberapa jauh peranan lembaga-lembaga dalam menjalankan peran sosialisasi tentang otonomi darah?

\section{Kerangka Pemikiran}

Persepsi adalah pengalaman tentang obyek, peristiwa, atau hubungan-hubungan yang diperoleh dengan menyimpulkan informasi dan penafsiran pesan. Persepsi ditentukan oleh faktor personal dan faktor situasional yang kemudian oleh David Krech dan Richard S. Crutchfield (1977) menyebutnya faktor fungsional dan faktor struktural. ${ }^{1}$ Faktor fungsional berasal dari kebutuhan, pengalaman massa lalu dan hal-hal lain yang termasuk apa yang kita sebut sebagai faktor personal. ${ }^{2}$ Perspektif kategori sosial berasumsi bahwa dalam masyarakat terdapat kelompok-kelompok sosial, yang reaksinya pada stimuli tertentu cenderung sama. Golongan sosial berdasarkan usia, jenis kelamin, tingkat pendapatan, pendidikan, tempat tinggal, dan keyakinan beragama menampilkan berbagai respon. ${ }^{3}$ Perspsepsi seseorang mengacu pada proses yang membuatnya menjadi tahu dan berpikir, menilai sifat-sifat kualitas dan keadaan internal seseorang. ${ }^{4}$ Selanjutnya persepsi diartikan sebagai proses memahami obyek dan fakta-fakta yang obyektif, yang didasarkan pada rangsangan obyek tersebut dan akan mempengaruhi perasaannya. ${ }^{5}$

Persepsi seseorang akan dipengaruhi oleh informasi dari berbagai sumber. Oleh karena itu kebutuhan manusia untuk ber-

'Desiderito diadopsi oleh Jalaluddin Rakhmat, 1998., hlm. 51.

2lbid., hIm. 55.

s/bid., hlm. 204.

4Lihat Renato Taguliri dalam Little John., 1978.

${ }^{5}$ Woodworth diadaopsi oleh Irtanto, dalam Jumal Media Massa, 2001, hlm. 88. 
komunikasi didorong oleh rasa ingin tahu atau membutuhkan sesuatu. Dengan demikian berkaitan dengan motivasi dan aspirasi seseorang, yaitu harapan dan citacita yang menyangkut kehidupan seseorang. Asumsi yang mendasari adalah bahwa untuk mendapatkan aspirasinya, maka individu membutuhkan informasi. Konsep informasi diartikan sebagai "penjelasan atau keterangan" mengenai sesuatu. Mengenai sesuatu dalam hal ini adalah informasi tentang otonomi daerah. Otonomi daerah yang dimaksudkan adalah berkaitan dengan UU No. 22 tahun 1999 dan UU No. 25 tahun 1999.

Oleh karena itu manusia memerlukan informasi, baik yang bersumber dari media massa maupun media interpersonal. Pemanfaatan media dan pemuasan kebutuhan (uses and gratifications) berasumsi bahwa pemamfaatan media diarahkan pada tujuan memuaskan kebutuhan tertentu, termasuk di dalamnya adalah informasi. ${ }^{6}$ Selanjutnya Mc. Quail (1996) membagi fungsi media antara lain yaitu media menyediakan informasi tentang lingkungan, media menyediakan kesempatan untuk melarikan diri dari kerutinan dan beban masalah dan sebagai wahana melepas emosi (escape/disverse), media sebagai wahana rujukan personal, eksplorasi realitas dan penguatan nilai (personal identity). ${ }^{7}$

Tidak itu saja, media massa memiliki kemampuan untuk memberitakan informasi secara efektif sehingga media mampu membuktikan peranannya untuk melayani tugas-tugas pembangunan. Selain itu media massa dapat memperluas cakrawala pemikiran, mampu menumbuhkan aspirasi dan merangsang masyarakat untuk bekerja lebih baik. ${ }^{8}$ Ada dua cara untuk memperoleh informasi, bersumber media massa dan lewat komunikasi interpersonal yaitu merupakan proses sosial dimana orangorang yang terlibat di dalam proses tersebut saling mempengaruhi. Dalam teori penyatuan (convergence theory) cenderung mandiri dan berfungsi sebagai bantuan "pilihan otonom" untuk melindungi kebebasan masyarakat mengambil pilihan tentang media mereka dan bentuk kebudayaan lainnya untuk menangkal, misalnya desakan perkembangan lembaga media sekuler "modern" yang berdasarkan pasar. ${ }^{9}$ surat kabar menentukan apa yang dibicarakan oleh kebanyakan orang, apa yang dipikirkan sebagian besar orang dan apa yang diharapkan orang dalam memecahkan masalah yang dihadapinya. ${ }^{10}$ Lebih lanjut Bemard C. Cohen (1963) dalam "the press and foreign policy' menjelaskan bahwa pers tidak mungkin banyak berhasil mempengaruhi apa yang dipikirkan orang, tapi lebih berhasil untuk membentuk persepsi orang tentang apa yang dianggapnya penting."

Sosialisasi otonomi daerah menjadi penting. Sosialisasi dapat dilakukan oleh lembaga pemerintah daerah dan non pemerintah. Media massa memainkan peran dalam sosialisasi. Asumsi dasar tertentu tentang dampak sosialisasi yang potensial dari media tampak dalam kebijakan pengendalian media, keputusan oleh media itu sendiri, serta norma dan harapan. Dalam asumsi media sebagai agen sosialisasi adalah besarnya perhatian yang ditujukan

'Lihat pada makalah Udi Rosadi sebagai materi pendidikan dan latihan penelitian Departemen Penerangan RI tanggal 1 Agustus 1999-30 Agustus 1999., hlm. 1.

${ }^{7}$ lbid., hlm. 2.

aLihat Willbur Schramm yang diadopsi oleh Eduard Depari dan Andrews, 1995., hlm. 47.

'Lihat pada Dennis Mc. Quail, 1996., hlm., 102.

${ }^{10}$ Norton Long diadopsi oleh Udi Rosadi., Op. cit. hlm. 1.

"Udi Rosadi, lbid. hlm. 2. 
pada media sebagaimana desosialisasi yang menentang dan mengganggu pembentukan nilai yang dilakukan orang tua, pendidik dan badan pengendalian sosial lainnya. Logika yang mendasari proposisi bahwa media memang mensosialisasi atau mendesosialisasi adalah pandangan tentang sosialisasi sebagai upaya mengajarkan norma dan nilai yang mapan melaluj ujian dan hukuman simbolis bagi berbagai jenis perilaku. Pandangan lain adalah bahwa hal itu merupakan proses belajar dimana kita mempelajari harapan yang sesuai dengan peran atau status tertentu dalam masyarakat. ${ }^{12}$

\section{Metode Penelitian}

Penelitian.ini bersifat eksploratif dengan mengambil lokasi di Kota Surabaya. Sedangkan populasinya adalah masyarakat yang sudah mempunyai hak-hak politik dalam pemilihan umum 1999. Sedangkan sampel size dalam penelitian ini telah ditentukan (sistem quota) dengan pertimbangan bahwa sifat dari penelitian ini adalah deskriptif dan eksploratif. Tehnik pengambilan sampel menggunakan quota sampling. Responden diambil berdasarkan jumlah proporsional menurut okupasi (jenis pekerjaan), yaitu sektor birokrasi (PNS,TNI/Polri, BUMN, BUMD dan lain-lain), sektor jasa (profesional, wiraswasta, pengusaha, kalangan akademi, sektor perdagangan, sektor informal serta pengangguran termasuk ibu-ibu rumah tangga). Pemilihan responden ini didasarkan pada faktor ekonomi politik yang berkait dengan masalah pelaksanaan otonomi daerah. Responden penelitian diambil 300 orang, diharapkan secara representatif dapat mewakili berbagai komponen masyarakat Kota Surabaya.

Sedangkan tehnik pengumpulan data menggunakan dua cara yaitu melalui wawancara dengan menggunakan daftar pertanyaan (interview guide) dengan tujuan untuk memperoleh data primer, sedangkan data sekunder diperoleh melalui wawancara mendalam (indept interview) pada key person yang mewakili tiga komponen masyarakat (political society, civil society dan market society), dan observasi serta studi perpustakaan.

\section{Hasil Penelitian dan Pembahasan}

Karakteristik Responden

Responden penelitian sejumlah 300 orang, sebagain besar berjenis kelamin lakilaki $(57,7 \%)$ dan sebagian lainnya wanita $(42,3 \%)$. Mereka berpendidikan SD $(2,3 \%)$, berpendidikan SLTP $(3,3 \%)$, SLTA $(19,7 \%)$, akademi/deploma $(27,3 \%)$, dan berpendidikan sarjana dan pasca sarjana $(61,3 \%)$. Mereka berasal dari suku bangsa yang bermacam-macam, Madura (11,7\%), WNI keturunan $(18,3 \%)$, dan mayoritas bersuku bangsa Jawa $(70,0 \%)$. Demikian juga agama yang mereka anut. bermacam-macam, secara kuantitatif yang paling banyak beragama Islam $(57,3 \%)$, beragama Kristen $(1,6 \%)$, Katholik $(6,7 \%)$, Hindu $(5,0 \%)$, Budha $(6,7 \%)$ dan ada juga yang menganut kepercayaan lainnya $(5,0 \%)$.

Dilihat dari jenis pekerjaannya bervariatif, ada yang sebagai PNS $(13,0 \%)$, mereka yang bekerja sebagai PNS mempunyai pangkat yang bervariasi dari golongan I sampai IV, dan bahkan mempunyai eselon yaitu eselon IV dan III. Ada pula mereka bekerja sebagai TNI dan Polri $(10,0 \%)$, bekerja sebagai karyawan swasta dan BUMN/D (16,7\%), pengusaha (10,3\%), sebagai pedagang atau wiraswasta $(14,7 \%)$, membuka toko atau warung $(11,7 \%)$, buruh industri $(11,7 \%)$, sebagai tukang $(2,0 \%)$ dan ada pula mereka yang bekerja sebagai seorang profesional $(10,0 \%)$. Sedangkan status mereka bermacam-macam, ada

12Dennis Mc. Quail., Op. Cit. hlm. 251. 
Topik: Persepsi Masyarakat Kota Terhadap Otonomi Daerah, Irtanto

yang duda/janda $(5,6 \%)$, belum kawin atau masih bujangan ( $13,7 \%)$, namun yang paling banyak mereka berstatus kawin $(80,7 \%)$.

\section{Aktivitas Sosial dan Orientasi Politik}

Kegiatan responden dalam kehidupan bermasyarakat di sekelilingnya terutama di kampungnya bervariasi, sebagai Ketua RT, RW, PKK, Badan Perwakilan Kelurahan, aktivis parpol dan lain sebagainya. Mereka yang menyatakan aktif di lingkungannya sebagai pengurus $(19,3 \%)$, aktif sebagai anggota $(30,0 \%)$, bahkan sebagian besar lainnya tidak aktif $(44,7 \%)$. Ada pula responden yang aktif sebagai pengurus di LSM $(19,3 \%)$, aktif sebagai anggota LSM $(17,7 \%)$, namun mereka banyak yang tidak aktif di LSM $(66,0 \%)$. Mereka yang aktif di parpol $(24,7 \%)$ dan yang tidak aktik di parpol $75,3 \%$.

Pada pemilihan umum 1999 tentunya mereka menyalurkan aspirasi politiknya bervariasi, satu dengan yang lainnya berbeda, namun ada pula yang tidak menyalurkan aspirasi politiknya atau disebut pula golongan putih. Orientasi politik mereka ada yang berafiliasi ke PBB $(0,3 \%)$, partai golongan karya $(5,0 \%)$, PPP $(5,7 \%)$, PAN $(3,0 \%)$, PKB $(24,0 \%)$, dan yang paling banyak mereka berafiliasi pada partai politik PDIP $(48,7 \%)$. Namum ada pula mereka yang menyalurkan aspirasi politiknya di luar partai itu.

Pilihan responden untuk tiap dewan perwakilan rakyat bervariasi pula. Mereka yang menyatakan sama pilihan partai untuk semua tingkat lembaga perwakilan rakyat (DPR Pusat, DPRD Propinsi, DPRD Kota) menunjukkan dominasi dalam pemilihan itu $(53,7 \%)$. Pilihan mereka ada yang berbeda antara tingkat pusat di satu pihak dan tingkat Propinsi dan Kota di lain pihak $(25,3 \%)$. Pilihan mereka yang berbeda untuk tingkat Propinsi dan Kota hanya $10,7 \%$, ada pula pilihannya bervariasi untuk tingkat pusat, Propinsi maupun Kota (10,3\%).

\section{Persepsi: Makna, Peluang dan Ekses Negatif Otonomi Daerah}

Mereka memaknai beragam terhadap pelaksanaan otonomi daerah itu sebagai implementasi UU No. 22 tahun 1999. Mereka memahami (memaknai) otonomi daerah sebagai peluang daerah untuk lebih mandiri, dan terlepas dari ketergantungan dari pemerintah pusat $(71,7 \%)$. Mereka yang berpandangan demikian itu berlatar belakang pekerjaannya yang membutuhkan profesionalitas yang tinggi, seperti kalangan akademik dan lingkungan bisnis (pengusaha) atau mereka memiliki tingkat pendidikan yang tinggi pula. Mereka yang berpandangan bahwa daerah harus mandiri itu $(71,7 \%)$ kebanyakan mereka mempunyai informasi yang cukup tentang baik dan buruknya otonomi daerah, baik itu bersumber dari media massa maupun tulisantulisan berupa jumal. Mereka berpendapat dalam era otonomi daerah, daerah harus bisa mengurus daerah sendiri tanpa adanya campur tangan pemerintah pusat $(91,7 \%)$. Hal ini hampir relatif sama hasil penelitian yang dilakukan terhadap masyarakat di propinsi Sulawesi Selatan yang menghasilkan bahwa apresiasi masyarakat terhadap otonomi daerah $32,0 \%$ menyatakan daerah mempunyai kewenangan untuk mengatur diri sendiri. ${ }^{13}$

Mereka juga memaknai otonomi daerah sebagai langkah yang sangat maju dan akan lebih banyak menguntungkan daerah otonom sendiri yaitu pajak akan lebih banyak diambil dan dimanfaatkan oleh daerah $(70,0 \%)$. Tidak seperti pada massa orde baru pajak dikuasai dan mengalir ke pemerintah pusat di Jakarta, dan banyak digunakan oleh pusat sendiri tanpa mem-

${ }^{13}$ Lihat hasil penelitian Baharuddin Dollah yang dilakukan di Sulawesi Selatan tentang "Studi Apresiasi Masyarakat Terhadap Otonomi Daerah, 2001, hlm. 28. 
perhatikan daerah. Mereka juga berpendapat bahwa pada massa orde baru daerah dimarginalkan dan pusat menyerap sumber yang ada di daerah. Mereka yang berpandangan demikian ini kebanyakan mempunyai latar belakang pendidikan yang memadai, dan mempunyai latar belakang pekerjaan sebagai karyawan swasta yang cukup mapan, pegawai negeri, kalangan pengusaha, yang berpenghasilan cukup serta kaum laki-laki. Namun mereka tidak sependapat kalau kekayaan daerah hanya dipenuntukkan untuk daerah sendiri $(50,0 \%)$ tanpa memperhatikan daerah lain yang berkekurangan.

Otonomi daerah juga dimaknai sebagai upaya pergeseran kekuasaan, pada rejim orde baru eksekutif memiliki kekuasaan yang lebih luas tidak dapat dikontrol oleh kekuatan lain. Tetapi kini di era otonomi daerah kekuasaan telah bergeser dari eksekutif peralih ke tangan legislatif $(93,7 \%)$. Menurut pandangan para kaum profesional, pengusaha ataupun mereka aktivis partai serta mereka yang berpendidikan tinggi dan memiliki status ekonomi mapan menganggap bahwa selama rezim orde baru diakui posisi legislatif sebagai subordinasi kekuasaan dan eksekutif tidak pernah terkontrol sehingga akibatnya korupsi tidak bisa dibendung lagi. Selain itu otonomi daerah menuntut aparatur daerah harus lebih profesional dalam melayani publik atau menangani pembangunan daerahnya $(93,0 \%)$.

Otonomi daerah akan berdampak positif bagi tumbuhnya partisipasi masyarakat dalam menentukan arah berkembangnya daerah itu sendiri $(67,0 \%)$. Tumbuhnya partisipasi masyarakat di daerah itu sebagai akibat pelaksnaan otonomi daerah yang tidak lagi menerapkan kebijakan massa mengambang seperti yang diterapkan oleh rejim orde baru. Kebanyakan masyarakat yang berpendidikan tinggi, berusia dewasa dan berpenghasilan cukup memaknai otonomi derah sebagai kebangkitan masyarakat untuk mengambil bagian dalam pembangunan daerah, baik pada proses pembuatan kebijakan publik maupun dalam mengimplementasikan kebijakan publik itu. Partisipasi masyarakat dalam era otonomi daerah dapat membuka peluang tumbuhnya budaya politik partisipan warga masyarakat. Kondisi seperti ini dapat dipandang sebagai paradigma yang sesuai dengan penyelenggaraan pemerintahan daerah sesuai dengan UU No. 22 tahun 1999 adalah demokrasi, karena pemerintahan harus secara transparan, penuh keterbukaan, dan semakin menumbuhkan peran dan kemampuan masyarakat untuk melibatkan diri dalam proses pengambilan keputusan penyelenggaraan pemerintahan dan pembangunan. ${ }^{14}$

Selain itu, masyarakat memahami bahwa otonomi daerah akan lebih menguntungkan daerah yang kaya atau memiliki sumber daya alam $(97,0 \%)$, secara otomatis daerah akan dapat memanfaatkan kekayaannya secara leluasa tidak lagi diatur oleh pusat. Konsekuensi lain dari pelaksanaan otonomi daerah menuntut hadirnya pemerintah yang efesien, efektif, transparan, akuntabel, bersih $(91,0 \%)$. Masyarakat yang berpandangan demikian ini kecenderungan berlatar belakang sebagai mahasiswa, pegawai negeri atau karyawan, kaum profesional dan pengusaha. Mereka juga menganggap hingga sampai saat ini birokrasi kita menjemukan, tidak efesien sama sekali, sangat lamban dan kinerjanya buruk, dan tidak transparan, masih saja menguasai masyarakat, tidak memberikan pelayanan sebagaimana layaknya. Masyarakat berpendapat pula bahwa otonomi daerah menuntut kerjasama yang semakin baik antara lembaga penyelenggara (eksekutif) dengan lembaga legislatif

\footnotetext{
${ }^{14}$ Soenyono, dalam Andi Malarangeng, 2001, hlm. 116.
} 
$(84,0 \%)$ tidak malah saling menjatuhkan satu dengan lainnya. Mereka yang berpandangan seperti ini kebanyakan pekerjaannya sebagai pegawai negeri, TNI/Polri, para pedagang kelas bawah, berpendidikan rendah dan status ekonomi belum mapan.

- Demikian juga masyarakat menyetujui bahwa otonomi daerah menuntut adanya kerjasama antar daerah otonom guna mengelola kepentingan atau resources bersama $(57,7 \%)$ terutama kerjasama untuk mengelola atau menghindari konflik yang tajam (62,0\%). Perlombaan antar daerah dapat pula menambah beban yang harus dipikul oleh masyarakat di setiap daerah tempat mereka mengadakan kegiatan sosial atau ekonomi yang bersifat lintas daerah. Perlu pula disadari, perlombaan-perlombaan semacam itu justru akan memperkecil dan mempersempit peluang daerah. Selain menghindari beban (burden) yang akan menghambat pelayanan umum secara wajar, kebijakan nasional dapat digunakan sebagai memperluas pelaung daerah memperoleh manfaat yang melampau batas teritoriainya masing-masing. Di sinilah pula kerjasama antar daerah, harmonisasi pengaturan dan harmonisasi kebijakan antar daerah. Dengan harmonisasi itu akan didapati kemudahan kegiatan antar daerah. Kerjasama dan harmonisasi hubungan antar daerah akan memperiluas jangkauan pernanfaatan sumber daya dan berbagai hasil suatu daerah. ${ }^{15}$

Tabel 1. Makna Otonomi Daerah

\begin{tabular}{|c|c|c|c|c|c|c|c|c|c|}
\hline \multirow{3}{*}{ No. } & \multirow{3}{*}{ Makna Otonomi Daerah } & \multicolumn{6}{|c|}{ Pendapat } & \multirow{2}{*}{\multicolumn{2}{|c|}{ Jumlah }} \\
\hline & & \multicolumn{2}{|c|}{ Setuju } & \multicolumn{2}{|c|}{$\begin{array}{l}\text { Tidak } \\
\text { Setuju }\end{array}$} & \multicolumn{2}{|c|}{$\begin{array}{l}\text { Tidak } \\
\text { Tahu }\end{array}$} & & \\
\hline & & $\uparrow$ & $\%$ & $f$ & $\%$ & $f$ & $\%$ & $f$ & $\%$ \\
\hline $\begin{array}{c}1 \\
2 \\
3 \\
4 \\
5 \\
6 \\
7 \\
\\
8 \\
9 \\
10 \\
11 \\
12 \\
13 \\
14\end{array}$ & $\begin{array}{l}\text { Daerah lebih mandiri. } \\
\text { Daerah harus bisa mengurus daerahnya sendiri } \\
\text { Pajak lebih banyak diambil daerah } \\
\text { Kekayaan hanya untuk daerah bersangkutan } \\
\text { Bupatimalikota lebih memiliki kekuasaan } \\
\text { Aparatur dituntut lebih profesional } \\
\text { Legislatif lebih memiliki kekuasaan dibanding } \\
\text { eksekutif } \\
\text { Masyarakat lebih berpartisipasi } \\
\text { Daerah kaya akan lebih diuntungkan } \\
\text { Menuntut pemerintahan yang efisien, efektif, } \\
\text { tranparan, akuntabel, dan bersih } \\
\text { Menuntut kerjasama yang makin baik antara } \\
\text { eksekutif dan legislatif } \\
\text { Menuntut kerjasama antar daerah otonom } \\
\text { guna mengelola kepentingan bersama } \\
\text { Menuntut kerjasama antar daerah otonon guna } \\
\text { mengelola konflik kepentingan } \\
\text { Menuntut kerjasama antar daerah otonom } \\
\text { guna memperjuangkan kepentingan secara } \\
\text { kolektif ke pusat } \\
\text { Pemerintah daerah lebih demokratis } \\
\text { Rakyat semakin diperhatikan } \\
\text { Perlu adanya koordinasi antara daerah otonom } \\
\text { dengan pihak pemerintah Propinsi }\end{array}$ & $\begin{array}{r}215 \\
275 \\
210 \\
135 \\
91 \\
279 \\
\\
281 \\
201 \\
291 \\
\\
273 \\
252\end{array}$ & $\begin{array}{l}71,7 \\
91,7 \\
70,0 \\
45,0 \\
30,3 \\
93,0 \\
93,7 \\
67,0 \\
97,0 \\
91,0 \\
84,0 \\
57,7 \\
62,0\end{array}$ & $\begin{array}{r}20 \\
1 \\
71 \\
150 \\
130 \\
19 \\
12 \\
34 \\
2 \\
1\end{array}$ & $\begin{array}{r}6,7 \\
0,3 \\
23,7 \\
50,0 \\
43,3 \\
6,3 \\
4,0 \\
11,3 \\
0,7 \\
0,3 \\
4,0 \\
2,7\end{array}$ & $\begin{array}{r}65 \\
24 \\
19 \\
15 \\
79 \\
2 \\
7 \\
7 \\
65 \\
7 \\
\\
26\end{array}$ & $\begin{array}{r}21,7 \\
8,0 \\
6,3 \\
5,0 \\
26,3 \\
0,7 \\
2,3 \\
21,7 \\
2,5 \\
8,7 \\
12,0\end{array}$ & $\begin{array}{l}300 \\
300 \\
300 \\
300 \\
300 \\
300\end{array}$ & $\begin{array}{l}100 \\
100 \\
100 \\
100 \\
100 \\
100 \\
\\
100 \\
100 \\
100\end{array}$ \\
\hline
\end{tabular}

Sumber : Data primer diolah

${ }^{15}$ Bagir Manan, 2001, him. ix. 
Masyarakat juga memaknai bahwa otonomi daerah diperlukan adanya kerjasama antara daerah otonom guna memperjuangkan kepentingan secara kolektif ke pemerintah pusat $(50,3 \%)$, seperti adanya Adeksi, Apeksi dan Apkasi. Kalau tidak ada kerjasama yang baik dikhawatirkan dalam jangka panjang otonomi daerah tidak berjalan dengan efektif. Dilihat dari latar belakang pendidikannya yang berpandangan demikian ini cukup tinggi, dan kecenderungannya berasal dari para pegawai negeri/ swasta, pengusaha, kaum profesional maupun statusnya mahasiswa serta para aktivis baik parpol maupun LSM. Sebagian besar masyarakat berpandangan bahwa otonomi daerah akan mendorong tumbuhnya pemerintahan daerah yang semakin demokratis $(84,0 \%)$. Kebanyakan masyarakat memaknai bahwa pemerintahan sekarang di era otonomi daerah ini semakin demokratis, pemerintah tidak dapat lagi memaksakan kehendaknya seperti pada jaman orde baru. Mereka yang berpandangan demikian itu hampir merata pada semua lapisan masyarakat (responden) baik yang berpendidikan tingg ataupun rendah, kalangan pegawai maupun para pedagang kaki lima, berpenghasilan rendah maupun tinggi. Dari sudut demokrasi, dalam arti formal, otonomi daerah diperlukan dalam rangka memperluas partsipasi masyarakat dalam pemerintahan. ${ }^{16}$

Mereka juga setuju kalau otonomi saerah itu berdampak pada rakyat yang akan semakin diperhatikan $(51,3 \%)$. Mereka yang berpendapat demikian ini terutama mereka yang pekerjaannya sebagai pedagang kecil, yang berpenghasilan menengah ke bawah, berpendidikan rendah dan mereka yang berusia muda. Di sisi lain, masyarakat ada yang pro dan kontra dalam menyikapi bagaimana hubungan antara daerah otonom dengan pihak Pemerintah Propinsi. Sebagian besar berpandangan bahwa otonomi daerah tidak perlu adanya koordinasi dengan pemerintah propinsi kalau ujung-ujungnya hanya berdampak. pada kurangnya kewenangan daerah otonom $(50,7 \%)$. Mereka yang berpandangan demikian itu berpendapat bahwa Kabupaten/Kota bukan bawahan Pemerintah Propinsi. Namun ada yang setuju kalau. daerah otonom harus berkoordinasi dengan pemerintah Propinsi dengan catatan tanpa mengurangi kewenangan daerah otonom $(46,7 \%)$. Mereka yang berpandangan demikian ini kecenderungannya berpendidikan tinggi, berpenghasilan menengah atas, para pegawai negeri maupun swasta, pengusaha dan kaum profesional lainnya, serta kalangan para mahasiswa. Hal ini sesuai dengan maksud dan mekanisme kubungan, bahwa daerah Propinsi tidak membawahkan Daerah Kabupaten/Kota, tetapi dalam praktek penyelenggaraan pemerintahan terdapat hubungan koordinasi, kerjasama, dan/atau kemitraan dengan Daerah Kabupaten/Kota dalam kedudukannya masing-masing sebagai daerah otonom. Sementara itu sebagai wilayah administratif, Gubernur selalu wakil Pemerintah melakukan hubungan pembinaan dan pengawasan terhadap Daerah Kabupaten dan Kota. ${ }^{17}$

Pelaksanaan otonomi daerah yang luas akan memberi berbagai peluang pada daerah (lihat tabel 2). Masyarakat berpendapat bahwa dengan adanya otonomi daerah, daerah akan lebih mengembangkan karier $(53,3 \%)$. Masyarakat yang perpandangan seperti itu terutama latar belakang pekerjaannya sebagai pegawai negeri, TNi/ Polri, aktivis partai maupun kalangan profesional. Namun sebagian besar pula yang tidak sependapat kalau dikatakan

${ }^{16} / \mathrm{bid}$, hlm. 59 :

${ }^{17}$ Op. cit, hlm. 119. 
bahwa dengan otonomi daerah dapat lebih mengembangkan usaha $(50,3 \%)$. Mereka yang mengatakan demikian itu karena beralasan bahwa dari pengalaman mereka selama ini yang dirasakan justru semakin sulitnya usaha akibat krisis ekonomi sejak 1998 itu dan ada faktor lain seperti pemungutan pajak ataupun retribusi yang cenderung tidak terkendali dan bermacammacam pungutan. Mereka yang berpandangan demikian ini terutama pekerjaannya sebagai pedagang menengah dan kecil, pengusaha dan berpendidikan rendah, berpenghasilan rendah, kaum wanita dan yang berusia muda.

\section{Tabel 2. Peluang Otonomi Daerah}

\begin{tabular}{|c|c|c|c|c|c|c|c|c|c|}
\hline \multirow{3}{*}{ No. } & \multirow{3}{*}{ Makna Otonomi Daerah } & \multicolumn{6}{|c|}{ Pendapat } & \multirow{2}{*}{\multicolumn{2}{|c|}{ Jumlah }} \\
\hline & & \multicolumn{2}{|c|}{ Setuju } & \multicolumn{2}{|c|}{$\begin{array}{l}\text { Tidak } \\
\text { Setuju }\end{array}$} & \multicolumn{2}{|c|}{$\begin{array}{l}\text { Tidak } \\
\text { Tahu }\end{array}$} & & \\
\hline & & $\mathbf{f}$ & $\%$ & f & $\%$ & $\mathbf{f}$ & $\%$ & $\mathbf{f}$ & $\%$ \\
\hline 1 & Dapat lebih mengembangkan karier & 160 & 53,3 & 130 & 43,3 & 10 & $\mathbf{3 , 4}$ & 300 & 100 \\
\hline 2 & Dapat lebih mengembangkan usaha & 133 & 44,3 & 151 & 50,3 & 16 & 5,4 & 300 & 100 \\
\hline 3 & Fasilitas umum lebih terjamin & 130 & 43,3 & 121 & 40,4 & 49 & 16,3 & 300 & 100 \\
\hline 4 & Kualitas pelayanan publik memeningkat & 182 & 60,7 & 101 & 33,7 & 17 & 5,6 & 300 & 100 \\
\hline 5 & Mendapat kemudahan usaha dari pemerintah & 151 & 50,3 & 62 & 20,7 & 87 & 29,0 & 300 & 100 \\
\hline 6 & Bebas mengembangkan/mendapat pinjaman & & & & & & & & \\
\hline & modal (investasi) & 154 & 51,3 & 96 & 32,0 & 50 & 16,7 & 300 & 100 \\
\hline 7 & Untuk meningkatkan ekonomi daerah & 276 & 92,0 & 21 & 7,0 & 3 & 1,0 & 300 & 100 \\
\hline
\end{tabular}

Sumber : Data primer diolah

Mereka juga berpandangan bahwa dengan adanya otonomi daerah justru daerah akan mengejar target-target PAD yang setinggi-tingginya. Masyarakat yang berpendapat demikian ini terutama yang mempunyai latar belakang pekerjaannya sebagai pengusaha, pedagang, kalangan profesional, maupun mereka sebagai aktivis di masyarakat, ataupun aktivis partai politik. Tetapi ada juga yang setuju bahwa otonomi daerah dapat mendorong tumbuhnya dunia usaha $(44,3 \%)$, terutama mereka kaum profesional, pengusaha, para wirausaha. Mereka berpandangan pula bahwa dalam era otonomi daerah dalam jangka panjang peredaran uang akan mengalir ke daerah, tidak lagi selalu menumpuk di Jakarta. Hasil penelitian yang demikian ini mendukung pendapat yang menyatakan bahwa untuk meningkatkan keuangan pemerintahan lokal salah satu syarat mutlak yang diperlukan dalam rangka meningkatkan keuangan daerah ini tidak lain adalah memberikan kekuasaan dan kewenangan yang cukup untuk meningkatkan penghasilan dan pajak. Pemerintah lokal harus mendapat mandat secara konstitusional dari dewan agar upaya pencarian pendapatan, baik dari sektor pajak maupun usaha lain memiliki 
legalitas. Dengan demikian daerah bebas melakukan berbagai pungutan tanpa dikontrol lagi oleh pusat. ${ }^{18}$

Berbagai peluang lainnya sebagai dampak positif diperlakukannya otonomi daerah adalah terjaminnya fasilitas umum $(43,3 \%)$ dan kualitas pelayanan publik oleh aparat pemerintah akan semakin meningkat $(60,7 \%)$. Mereka yang cenderung berpendapat seperti itủ berlatar belakang sebagai pedagang kecil, buruh, mereka yang berpenghasilan menengah ke bawah, berpendidikan tinggi maupun rendah, kaum laki-laki dan berusia muda. Terjaminnya fasilitas umum maupun semakin meningkatnya kualitas pelayanan publik oleh aparat di era otonomi daerah disebabkan oleh karena berbagai tuntutan publik yang semakin intens dan semakin sadarnya publik akan hak-haknya. Selain itu, masyarakat cenderung berpandangan bahwa dengan adanya otonomi daerah masyarakat dalam jangka panjang akan mendapat kemudahan usaha dari pemerintah $(50,3 \%)$ dikarenakan pemerintah daerah ingin mendapatkan investasi yang sebesar-besarnya dari para pemilik modal dengan tujuan agar daerahnya semakin berkembang. Demikian juga dapat menyerap tenaga kerja yang sebanyak-banyaknya maupun mendapatkan dana dari pajak usaha. Mereka yang berpandangan demikian itu kebanyakan sebagai aktivis partai (politikus), pegawai negeri, karyawan, pedagang, pengusaha maupun kaum profesional, kaum wanita, berpenghasilan menengah atas dan mereka yang berusia muda maupun ada yang sebagian usia lanjut.

Masyarakat juga berpandangan bahwa otonomi daerah dalam jangka panjang berdampak poisitif terhadap kebebasan mendapatkan pinjaman modal $(51,3 \%)$. Tidak itu saja, otonomi daerah pada massa ke depan bertujuan untuk meningktakan ekonomi daerah $(92,0 \%)$.Mereka ber- pandangan demikian itu karena adanya deregulasi kebijakan ekonomi yang dibuat oleh daerah itu sendiri. Meningkatnya ekonomi ini sebagai dampak positif diperbolehkannya daerah mengambil berbagai kebijakan di bidang ekonomi yang sebelumnya daerah tidak diberi kesempatan. Otonomi daerah itu sendiri bukanlah tujuan, melainkan cara dan strategi dalam rangka mewujudkan demokrasi yang sehat, adil, dan berorientasi kesejahteraan bagi seluruh bangsa Indonesia. ${ }^{19}$

Otonomi daerah tidak selamanya berekses positif namun ada pula dampak negatifnya kalau tidak disikapi dengan penuh hati-hati (lihat tabel 3). Masyarakat cenderung berpandangan bahwa otonomi daerah kalau tidak disikapi dengan hatihati akan menimbulkan gejolak/instabilitas politik di daerah yang semakin menggila $(70,3 \%)$. Hal itu disebabkan karena akumulasi kebencian dan trauma daerah kepada pusat akibat penerapan sistem politik yang sangat otoriter yang diterapkan oleh orde baru yang tidak akomudatif terhadap kepentingan/aspirasi daerah.

Demikian juga sebagian besar masyarakat mempersepsikan otonomi daerah akan menampakkan perebutan kekuasaan $(52,0 \%)$. Perebutan kekuasaan ini dinilai sesuatu hal yang wajar sebagai perwujudan demokrasi, dan sebagai dampak adanya euforia kebebasan politik yang mereka alami. Itupun akan bersifat temporer. Ada juga tidak sependapat bahwa otonomi daerah akan menimbulkan kerugian yang ditanggung oleh daerah berupa perebutan kekuasaan politik yang semakin parah $(43,3 \%)$. Hal itu dinilainya mengada-ada, mereka berpandangan bahwa perebutan

${ }^{18}$ Lihat Asep Nurjaman dalam Andi A. Malarangeng, 2001, hlm. 132-133.

igyamsuddi Haris, 2000, hlm. 67. 
politik itu bersifat temporer, perebutan politik itu dinilainya tidak akan menimbulkan konflik yang tajam yang dapat mengarah pada perpecahan. Sejalan dengan perjalanan waktu dan sebagai proses pembelajaran demokrasi itu sendiri mereka akan dewasa terhadap pemahaman politik. Ekses negatif lainnya yang ditanggung oleh daerah sebagai dampak diterapkan otonomi daerah adalah berupa meluasnya gejala politik uang (money politics) di semua tingkatan politik $(64,0 \%)$, pertentangan antara BupatiWalikota dengan dewan yang semakin tajam. Demikian juga otonomi daerah berdampak pada rakyat yang akan terbebani oleh berbagai pajak ( $67,3 \%)$. Hal ini disebabkan karena daerah akan mengejar target-target pendapat ahli daerah. Selain itu akibat hanya mengejar target-target pendapatan asli daerah sumber daya lokal akan dieksploitasi secara besar-besaran $(56,7 \%)$.

Otonomi daerah yang dititik beratkan pada Kabupaten ataupun Kota itu akan memberi peluang yang sangat besar terhadap peran partai politik. Akibat semakin besamya peran parpol ini akan berpengaruh terhadap kelangsungan pemerintahan, yaitu parpol akan terlalu berkuasa atas pemerintahan (46,7\%). Partai politikpun akan mengedepankan kepentingannya.

\section{Tabel 3. Ekses Negatif Otonomi Daerah}

\begin{tabular}{|c|c|c|c|c|c|c|c|c|c|}
\hline \multirow{3}{*}{ No. } & \multirow{3}{*}{ Makna Otonomi Daerah } & \multicolumn{6}{|c|}{ Pendapat } & \multirow{2}{*}{\multicolumn{2}{|c|}{ Jumlah }} \\
\hline & & \multicolumn{2}{|c|}{ Setuju } & \multicolumn{2}{|c|}{$\begin{array}{l}\text { Tidak } \\
\text { Setuju }\end{array}$} & \multicolumn{2}{|c|}{$\begin{array}{l}\text { Tidak } \\
\text { Tahu } \\
\end{array}$} & & \\
\hline & & $t$ & $\%$ & $f$ & $\%$ & $f$ & $\%$ & f & $\%$ \\
\hline $\begin{array}{l}1 \\
2 \\
3 \\
4 \\
4 \\
5 \\
6 \\
7 \\
8 \\
9 \\
10 \\
11 \\
12 \\
13 \\
13 \\
14 \\
15 \\
16\end{array}$ & $\begin{array}{l}\text { Memunculkan Instabilitas politik } \\
\text { Perebutan kekuasaan makin nampak } \\
\text { Semakin tajam pertentangan antara Bupati/ } \\
\text { Walikota dengan dewan } \\
\text { Gejala meluasnya politik uang } \\
\text { Rakyat akan terbebani berbagai pajak } \\
\text { Aparatur pemerintah lebih berkuasa } \\
\text { BupatiWalikota menjadi raja kecil } \\
\text { Parpol terlalu berkuasa atas pemerintahan } \\
\text { Terjadi persaingan dan egoisme daerah } \\
\text { Sumber daya lokal akan dieksploitasi } \\
\text { Pemerintah daerah akan bersikap otoriter } \\
\text { DPRD lebih berorientasi pada internalnya } \\
\text { daripada kepentingan rakyat } \\
\text { Otonomi daerah dapat mengakibatkan } \\
\text { desintegrasi bangsa } \\
\text { KKN akan merajalela di daerah } \\
\text { Menumbuhkan etnisitas, kesukuan } \\
\text { Banyak pihak mementingkan golongannya }\end{array}$ & \begin{tabular}{r|}
211 \\
156 \\
172 \\
192 \\
202 \\
101 \\
51 \\
140 \\
191 \\
170 \\
61 \\
101 \\
21 \\
170 \\
189 \\
241
\end{tabular} & $\begin{array}{r}70,3 \\
52,0 \\
57,3 \\
64,0 \\
67,3 \\
33,7 \\
17,0 \\
46,7 \\
63,7 \\
56,7 \\
20,3 \\
\\
33,7 \\
7,0 \\
56,7 \\
63,0 \\
80,3\end{array}$ & \begin{tabular}{|r}
78 \\
130 \\
\\
101 \\
89 \\
85 \\
181 \\
191 \\
130 \\
54 \\
91 \\
151 \\
\\
100 \\
\\
236 \\
21 \\
10 \\
12
\end{tabular} & $\begin{array}{r}26,0 \\
43,3 \\
33,7 \\
29,7 \\
28,3 \\
60,3 \\
63,7 \\
43,3 \\
18,0 \\
30,3 \\
50,3 \\
33,3 \\
78,7 \\
40,3 \\
3,3 \\
4,0\end{array}$ & $\begin{array}{r}11 \\
14 \\
\\
27 \\
19 \\
13 \\
18 \\
58 \\
30 \\
55 \\
39 \\
88 . \\
99 \\
\\
43 \\
9 \\
101 \\
36\end{array}$ & $\begin{array}{r}3,7 \\
4,7 \\
9,0 \\
6,3 \\
4,4 \\
6,0 \\
19,3 \\
10,0 \\
18,3 \\
13,0 \\
29,4 \\
\\
33,0 \\
14,3 \\
3,0 \\
33,7 \\
12,0\end{array}$ & $\begin{array}{l}300 \\
300 \\
300 \\
300 \\
300 \\
300 \\
300 \\
300 \\
300 \\
300 \\
300 \\
300 \\
\\
300 \\
300 \\
300 \\
300\end{array}$ & $\begin{array}{l}100 \\
100 \\
100 \\
100 \\
100 \\
100 \\
100 \\
100 \\
100 \\
100 \\
100\end{array}$ \\
\hline
\end{tabular}

Sumber : Data primer diolah 
Ekses negatif lain dari pelaksanaan otonomi daerah diperkirakan akan mengganggu hubungan antar daerah otonom yaitu terjadi persaingan dan egoisme daerah $(63,7 \%)$. Mereka berpandangan bahwa otonomi daerah memberi kekuasan politik kepada parpol yang sangat besar yang direpresentasikan dalam legislatif. Besarnya kekuasaan legislatif (DPRD) semakin memberi peluang untuk mengontrol eksekutif. Akibatnya akan banyak terjadi benturan antara dewan dengan eksekutif, sehingga akan menimbulkan semakin meluasnya politik uang atau bahkan KKN $(56,7 \%)$. Dengan otonomi yang seluasluasnya kewenangan DPRD menjadi membengkak, sehingga mudah sekali terjadi otoriterisme dalam kerja DPRD khususnya dalam fungsi pengawasan terhadap eksekutif. 20 Masyarakat menghendaki agar tidak hanya berorientasi pada kepentingan yang sempit, golongan dan parpolnya. Masyarakat menilai bahwa yang terjadi selama ini masih mementingkan golongan yang sempit $(80,3 \%)$. Dampak negatif dari otonomi daerah akan berakibat pada DPRD dan kepala daerah akan lebih banyak berorientasi kepada kepentingan partai daripada kepentingan rakyat, akan terbuka pintu yang lebar terjadinya kolusi antara eksekutif dengan legislatif. ${ }^{21}$

Masyarakat berpendapat pula otonomi daerah tidak akan berdampak negatif terhadap desintegrasi bangsa $(78,7 \%)$, tetapi akan menumbuhkan etnisitas, kesukuan, primordialisme $(63,0 \%)$. Masalah lain yang dihadapi adalah eksklusivisme hubungan antar daerah. Masing-masing daerah berlomba-lomba mengatur diri sendiri demi kepentingan daerah. ${ }^{22}$ Otonomi daerah yang. seluas-luasnya akan menimbulkan semangat kedaerahan yang tidak terkendali, hal ini dapat mengakibatkan perpecahan yang mungkin sekali bermuara kepada hilangnya semangat kesatuan dan persatuan. Demikian juga dalam merekrut pegawai daerah, masing-masing daerah akan mengutamakan putra daerah dan menutup kemungkinan masuknya penduduk lain daerah. ${ }^{23}$

\section{Informasi Otonomi Daerah}

Cara responden untuk memperoleh informasi tentang otonomi daerah melalui dua sumber yaitu melalui media komunikasi interpersonal dan media massa. Mereka memperoleh informasi tentang otonomi daerah dengan melakukan komunikasi interpersonal itu kecendenungannya berdialog dengan teman bekerja $(40,3 \%)$ dan tokoh masyarakat $(27,0 \%)$ dan mereka jarang sekali dengan tetangganya $(8,3 \%)$. Mereka dalam melakukan dialog tersebut kecenderungannya lebih senang bertukar pikiran $(54,0 \%)$, namun ada juga dengan cara adu argumentasi atau berdebat $(20,7 \%)$. Mereka berdialog tentang otonomi daerah bertujuan untuk menambah wawasan, kalau perlu disumbangkan kepada para pengambil policy. Demikian pula para profesional akan lebih peduli terhadap kehidupan bermasyarakat sehingga tujuan mereka berdialog lebih cenderung untuk mencari alternatif pemecahannya.

Sedangkan materi yang mereka dialogkan adalah masalah pajak daerah $(44,0 \%)$ yang kemungkinan akan memberatkan masyarakat. Otonomi daerah kalau tidak pandai-pandai memanfaatkan sumber daya alam akan berdampak terhadap perekonomian masyarakat yang akan semakin berat akibat beban-beban pajak yang harus ditanggungnya, apalagi daerahnya minim

\footnotetext{
20Lihat Muchsan, 2000, him. 359.

$21 /$ bid.

2Bagir Manan, op. cit, hlm. Viii.

${ }^{23}$ Op.cit, 358-359.
} 
sumber daya alamnya. Demikian juga ada kecenderungan mereka membicarakan tentang persoalan keuangan daerah $(23,7 \%)$ dan masalah aparatur pemerintah daerah yang dituntut harus profesional dalam memberikan pelayanan kepada masyarakat $(23,7 \%)$. Mereka jarang sekali berbicara masalah perimbangan kewenangan pusat dengan daerah $(14,7 \%)$ atau masalahmasalah kewilayahan daerah otonomi $(4,0 \%)$.

Media massa juga dipakai sebagai sarana untuk mendapatkan informasi tentang otonomi daerah. Media massa RRI cenderung tidak pernah disentuh oleh mereka $(56,4)$, walaupun mereka ada yang memanfaatkan media massa RRI hanya kadang-kadang $(30,3 \%)$. Sumber informasi yang sering dimanfaatkan cenderung berasal dari Televisi swasta $(45,3 \%)$ dan surat kabar yang berskala lokal $(58,3 \%)$ dan bersumber dari berbagai majalah $(55,0 \%)$, media massa TVRI $(45,0 \%)$ maupun radio swasta $(35,7 \%)$. Sedangkan surat kabar yang berskala nasional (lbu kota) cenderung tidak pernah disentuh $(35,7 \%)$. Demikian juga dalam memperoleh informasi tentang otonomi daerah media internet ada kecenderungan kuat tidak digunakannya sama sekali $(85,0 \%)$. Mereka yang menyentuh surat kabar nasional maupun internet kebanyakan para profesional, elit politik serta mereka yang mempunyai status ekonomi dan sosial yang mapan. Kondisi semacam ini relatif sama dengan penelitian yang dilakukan di Propinsi Sulawesi Selatan dengan mengambil sampel 250 responden. Ada kecenderungan kuat bahwa 51,6\% masyarakat Sulawesi Selatan mengetahui informasi tentang otonomi daerah berasal dari televisi dan $16,0 \%$ dari surat kabar. ${ }^{24}$

Format media massa yang dipergunakan untuk memperoleh informasi tentang otonomi daerah sangat bervariasi. Media
$R R l$ yang disenangi dalam bentuk interaktif $(33,7 \%)$ dan wawancara dengan para ahli atau para profesional $(30,3 \%)$. Sedangkan radio swasta yang mereka senangi kecenderungannya adalah dalam ragam wawancara $(47,3 \%)$, demikian juga mereka dalam memperoleh informasi tentang otonomi daerah dari TVRI dalam format wawancara $(31,7 \%)$ dan berita mendalam. Lain halnya dengan TV swasta, mereka untuk memperoleh informasi tentang prospek otonomi daerah cenderung pada acara dialog interaktif $(35,3 \%)$ dan wawancara $(26,3 \%)$. Mereka memperoleh informasi otonomi daerah yang bersumber dari surat kabar harian lokal maupun nasional cenderung menyenangi bentuk berita langsung maupun berita yang dikemas sedemikian mendalam. Dari para pembaca surat kabar nasional misalnya dalam format berita mendalam $(54,7 \%)$. Sedangkan surat kabar harian lokal mereka senang format berita langsung $(43,7 \%)$ dan berita mendalam $(31,3 \%)$. Informasi otonomi daerah yang diperoleh dari majalah dalam bentuk ulasan yang mendalam $(59,0 \%)$.

Sedangkan mereka yang membaca jurnal kebanyakan dalam bentuk tulisantulisan ilmiah ataupun hasil-hasil penelitian. Itupun hanya kalangan terbatas, terutama para profesioanl atau para intelektual. Mereka beranggapan bahwa informasi dari jurnal akan lebih akurat, dan tingkat validitasnya lebih dapat dipercaya. Masyarakat dalam mencari informasi otonomi daerah cenderung bersumber dari media massa,

${ }^{24}$ Lihat hasil penelitian yang dilakukan oleh Baharrudin Dollah dilakukan di Sulawesi Selatan tentang Studi Apresiasi Masyarakat Terhadap Otonomi Daerah pada Jurnal Penerangan, Komunikasi dan Media Massa, 2001, hlm. 27. 
hal ini sesuai dengan teori persuai dan informasi yang menyatakan bahwa mengapa orang memperhatikan media massa, satu kemungkinan jawabannya ialah karena mereka berusaha menambah khazanah pengetahuan (informasi) dan atau memperoleh bimbingan (opini). Dipandang dari fungsi ini, media massa mendifusikan informasi dan mempersuasi. Teori ini menetapkan informasi menurut kemampuannya mengurangi kepastian atau ketakteraturan situasi pada ujung penerima. ${ }^{25}$ Media massa memang tidak dapat mempengaruhi orang untuk mengubah sikap, tetapi media massa cukup berpengaruh terhadap apa yang dipikirkan orang. ${ }^{26}$

Selain itu masyarakat menganggap bahwa informasi otonomi daerah adalah hal yang penting $(50,7 \%)$, tetapi ada pula yang menganggap tidak penting $(23,3 \%)$ dan ada yang tidak tahu menahu $(26,0 \%)$. Hasil penelitian ini sesuai dengan fungsi agenda setting media massa adalah kemampuan media massa untuk menseleksi dan menekankan beberapa topik, menyebabkan publik menerima topik tersebut sebagai topik yang penting. ${ }^{28}$

\section{Sosialisasi Otonomi Daerah}

Otonomi daerah harus disosialisasikan kepada masyarakat terutama yang menyangkut pelaksanaan UU No. 22/1999 dan UU No. 25/1999. Sosialisasi dipandang penting karena pemerintah daerah harus mendapat dukungan dari masyarakat, dengan harapan agar pembangunan itu berhasil dengan baik. Selama pelaksanaan otonomi daerah ini ada sebagian besar responden merasa tidak pernah mendapat sosialisasi dari pihak manapun $(76,3 \%)$, sedangkan sebagian kecil yang merasa pernah mendapatkan sosialisasi $(23,7 \%)$. Kecilnya frekuensi yang memperoleh sosialisasi itu sekaligus menggambarkan bahwa instansi terkait, lembaga-lembaga kemasyarakatan, maupun lembaga lainnya berarti tidak berperan dalam mendewasakan politik rakyat. Mereka yang-sebagian kecil menyatakan pemah mendapatkan sosialisasi itu cendenung berasal dari lembaga politik atau partai politik $(45,1 \%)$. Itupun karena mereka aktivis partai politik, baik sebagai elit politik lokal maupun regional.

Tidak berjalannya lembaga-lembaga sosialisasi itu dapat dibuktikan dengan pernyataan mereka yang tidak pernah mendapat sosialisasi dari lembaga pemerintah daerah $(97,2 \%)$. Demikian juga mereka menyatakan tidak pernah mendapat sosialisasi dari lembaga pendidikan $(50,7 \%)$, lembaga kemasyarakatan $(56,3 \%)$, lembaga keagamaan $(67,9 \%)$ maupun LSM $(66,2 \%)$. Mereka yang pemah mendapatkan sosialisasi karena status pekerjaannya sebagai PNS atau TNI/Polri. Karena minimnya peranan lembaga sosialisasi itu masyarakat berinisiatif untuk memperoleh informasi otonomi daerah, seperti dari media massa televisi, radio, media massa cetak seperti surat kabar harian baik terbitan lokal maupun nasional (lbu Kota), majalah, dan mereka status sosial dan ekonomi yang mapan juga dari internet, jurnal atau bahkan mereka mengikuti berbagai seminar. Kondisi demikian yang menunjukkan bahwa kebanyakan masyarakat mencari informasi melalui media massa mendukung logika yang mendasari proposisi bahwa media memang mensosialisasi atau mendesosialisasi adalah pandangan tentang sosialisasi sebagai upaya mengajarkan norma dan nilai yang mapan melalui ujian

${ }^{25}$ Dan Nimmo, 1993, hlm. 172-173.

${ }^{26}$ Diadopsi oleh Irtanto dari Jalaluddin Rakhmat, 2001, hlm, 98.

${ }^{27}$ Udi Rosadi, op. cit. 1999, hlm. 1.

${ }^{28}$ Dennis Mc, 1996, hlm. 251. 
dan hukuman simbolis bagi berbagai jenis perilaku. Pandangan lain adalah bahwa hal itu merupakan proses belajar dimana kita mempelajari harapan yang sesuai dengan peran atau status tertentu dalam masyarakat. ${ }^{28}$

Ada benamya media massa menimbulkan dampak sosialisasi. Dalam masyarakat modern media massa mengambil posisi sebagai media komunikasi yang sekaligus berperan sebagai media sosialisasi. Masyarakat yang mengandalkan industri media massa, maka peran lembaga-lembaga sosialisasi semakin melemah keberadaannya, sehingga wajar kalau masyarakat Surabaya yang metropolis ini dalam mencarai informasi lebih cenderung mengandalkan pada media massa cetak maupun elektronika. Apalagi didukung oleh adanya kebebasan pers yang memungkinan masyarakat sebebas-bebasnya untuk memperoleh informasi. Beralihnya peran sosialisasi yang diambil oleh media massa, barangkali dapat dikaitkan dengan kemampuan media massa yang cepat dalam menyesuaikan perannya untuk menjangkau khalayaknya dengan dukungan teknologi yang modern. Keefektifan media massa adalah ketidaksegeraan umpan balik, juga ikut mempengaruhi peran dan penampilan saluran dalam komunikasi politik, termasuk pelaksanaan sosialisasi politik..$^{29}$ Demikian pula peranan media massa cukup besar dan lebih efektif dalam pemberian pemahaman/pengetahuan informasi kepada khalayak karena media massa mempunyai fungsi tertentu yaitu media massa memberi informasi, media massa dapat membantu kita untuk menyusun agenda, menyusun jadwal kehidupan sehari-hari, media massa membantu untuk berhubungan dengan pelbagai kelompok masyarakat lain di luar masyarakat kita, media massa membantu mensosialisasi pribadi manusia. ${ }^{30}$

\section{Penutup}

Otonomi daerah yang berlaku sejak 1 Januari 2001 dipersepsi oleh sebagian besar masyarakat sesuatu hal yang sangat positif. Mereka berpandangan bahwa dengan adanya otonomi daerah, daerah akan lebih berkembang, dan kreativitas masyarakat akan tumbuh.

Demikian pula dengan otonomi daerah, daerah mendapatkan berbagai peluang yang begitu besar seperti dapat meningkatkan ekonomi daerah, memperoleh kemudahan untuk mendapatkan modal usaha, kualitas pelayanan publik akan lebih meningkat dan daerah akan dapat mengembangkan kariemya. Sebagai ekses negatif diterapkan otonomi daerah, antara lain kemungkinan gejolak politik didaerah akan meningkat. Mereka berpandangan pula bahwa otonomi daerah akan menyebabkan beralihnya pola-pola KKN.

Beragamnya persepsi tersebut dipengaruhi oleh bagaimana memanfaatkan sumber informasi tentang otonomi daerah. Pemanfaatkan informasi cenderung dari media massa terutama televisi dan surat kabar harian, namun ada pula yang memanfaatkan media intemet terutama mereka yang status ekonominya mapan/tinggi dan kaum profesional. Selain bersumber pada media massa juga melalui dialog atau diskusi dengan teman sepekerjanya. Bagi mereka yang mempunyai status sosial yang tinggi dan seseorang profesional selain bersumber pada media massa dan internet, maupun bersumber pada tulisantulisan ilmiah seperti jurnal, seminar. Masyarakat dalam memanfaatkan sumber

29Lihat tulisan Syarifuddin Akbar, tentang "Komunikasi dan Sosialisasi Politik" dalam Jurnal Penerangan, Komunikasi dan Media Massa, 2001, him. 58. Vol. Ill. No. 6. BPPI Makassar.

${ }^{30}$ Alo Liliweri, 1991, him. 42. 
informasi tentang otonomi daerah cenderung dari media massa, intemet ataupun melalui berbagai dialog itu karena lembaga sosialisasi belum berfungsi sebagai mana semestinya.

Dengan demikian faktor yang mempengaruhi persepsi tentang otonomi daerah lebih banyak karena sosialisasi secara tidak langsung yang dilakukan oleh media massa, baik cetak maupun elektronika, sehingga otonomi daerah dipersepsikan berbeda antara orang satu dengan lainnya.

\section{Daftar Pustaka}

Akbar, Syarifuddin, "Komunikasi dan Sosialisasi Politik" "dalam Jumal Penerangan.

Komunikasi dan Media Massa, Vol. III, No.6. BPPI Makassar, 2001.

Depari, Eduard dan Mac Colin, Andrews (Ed), 1995. Peranan Komunikasi Massa dalam Pembangunan, Yogyakarta: Gajah Mada University Press.

Dollah, Baharrudin, 2001. "Studi Apresiasi Masyarakat Terhadap Otonomi Daerah" dalam Jurnal Penerangan, Komunikasi dan Media Massa ( $\mathrm{Pe}$ komnas), Vol. III, No. 6. BPPI Makasar.

Haris, Syamsuddin, 2000. "Otonomi, Federasi atau Demokratisasi“ dalam Jurnal Masyarakat Indonesia, Jilid XXVI, No. 1. LIPI, Jakarta.

Ittanto, 2001. "Persepsi Masyarakat Desa Terhadap Peranan Media Massa" dalam Jumal Penelitian Media Massa, Vol. 4 No. 8, Balai Pengkajian dan Pengembangan Informasi Surabaya.

Liliweri, Alo, 1991. Memahami Peran Komunikasi Massa dalam Masyarakat, Bandung: Citra Aditya Bakti.

Mc. Quail, Denis and Seven Weindahl, 1995. Model-Model Komunikasi, Institut IImu-IImu Sosial dan IImu Politik, Jakarta.
Mc. Quail, 1996. Teori Komunikasi Massa, Jakarta: Erlangga.

Malaranggeng, A. Andi Dkk, 2001. Otonomi Daerah Perspektif Teoritis dan Praktis, Malang: Bigraf.

Manan, Bagir, 2001. Menyonsong Fajar Otonomi Daerah, Pusat Hukum (PSH), Fakultas Hukum UII, Yogyakarta.

Muchsan, "Kajian Yuridis Undang-Undang No. 22 tahun 1999" dalam Jumal limuIImu Sosial UNISIA, No. 42/X/XXIIII/ IV, UII,Yogyakarta, 2000.

Nasution, M. Arif Dkk, 2000. Demokratisasi dan Problema Otonomi Daerah, Bandung: Mandar Maju.

Nimmo, dan, Komunikasi Politik, 1993. Bandung: Rosdakarya.

Nurjaman, Asep, 2001. dalam Andi A Malaranggeng Dkk, Otonomi Daerah Perspektif Teoritis dan Praktis, Malang: Bigraf.

Rahkhmat, Jalaluddin, 1998. Psikologi Komunikasi, Bandung: Remaja Rosdakarya.

Rosadi, Udi "Teori dan Model Penelitian Efek Agenda Setting Media Massa" makalah Pendidikan dan Latihan Penelitian Deppen RI, Jakarta,1999.

Soenyoso, 2001. "Prospek Pelaksanaan Otonomi daerah Berdasarkan UU No. 22 tahun 1999 tentang Pemerintah Daerah", dalam Andi A Malaranggeng, Malang: Bigraf.

Surabaya dalam Angka 2000, BPS Surabaya 2000.

UU No. 22 tahun 1999 tentang pemerintahan daerah.

UU. No.25/1999 tentang perimbangan keuangan antara Pemerintah Pusat dan Daerah. 